\title{
MeASURING OF THE COMPANy OPERATIONS EFFICIENCY
}

\author{
HerzoG, N.V.; POLAJNAR, A. \& PALCiC, I.
}

Abstract: The field of performance measurement is often discoussed at this time. Traditional criteria which were based especially on cost have become inadequate, especially because of changes in the nature of work, the rise of modern manufacturing concepts, changes of roles in companies, new demands of business environment and development of information technology.

The article presents results of a survey research carried out in 73 Slovenian enterprises from mechanical and electro- mechanical branch. Based on the results of a survey research a set of performance measurements indicators was developed. New variables were developed using reliability and validity analysis. Recycling and modernisation of implementation measuring systems on one hand refers to innovations of accountancy systems, especially regarding treatment of expenses which are based on activities, and on the other hand on the expansion of the field of measuring, the so-called non-cost measurements which are not economic-financial in nature, but come from the customer needs.

Key words: performance measurement, manufacturing company, empirical research, survey
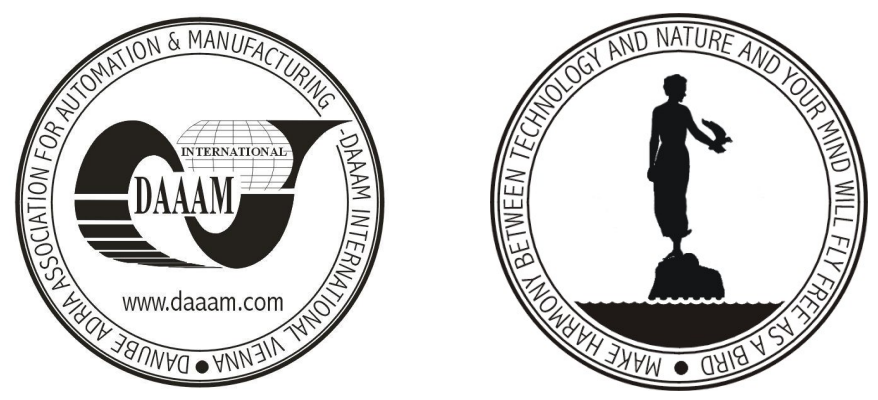

Authors' data: Ph.D. Ass. Prof. Herzog, N[atasa] V[ujica]; Dr. Sc. Polajnar, A[ndrej]; Ph.D. Ass. Prof. Palcic, I[ztok], University of Maribor, Faculty of Mechanical Engineering, Smetanova 17, SI - 2000 Maribor, Slovenia, natasa.vujica@uni-mb.si, andrej.polajnar@uni-mb.si,iztok.palcic@uni-mb.si,

This Publication has to be referred as: Herzog, N.V.; Polajnar, A. \& Palcic, I. (2007). Measuring of the Company Operations Efficiency, Chapter 11 in DAAAM International Scientific Book 2007, B. Katalinic (Ed.), Published by DAAAM International, ISBN 3-901509-60-7, ISSN 1726-9687, Vienna, Austria

DOI: $10.2507 /$ daaam.scibook.2007.11 